\title{
Who Are the Poor? Theology of Liberation in Eastern Europe Under Communism
}

\author{
PHILIP WALTERS
}

The 'liberation theology' of Latin America is well known. Less well known is the fact that a 'theology of liberation' developed in Eastern Europe before the fall of communism. It was not systematically developed: it could hardly have been so, given the pressures there against any kind of creative theological speculation. In the various countries and churches where such a theology did develop, however, the common features it shared were remarkable.

In this article I shall be looking mainly at theologies produced in Catholic and Orthodox milieux: in the 'Oasis' (later the 'Light-Life') movement in Poland founded by Fr Franciszek Blachnicki; in the basis community 'A Bokor' ('The Bush') founded by the Piarist priest Fr György Bulányi in Hungary; and in the 'Christian Seminar on Problems of the Religious Renaissance' founded by young Orthodox Christians in Russia in the mid-1970s.

I will compare what Eastern Europeans have to say about 'liberation' with the ideas of Latin Americans, and in doing so I will isolate areas of semantic misunderstanding and also areas of substantial agreement or disagreement. I will thereby identify those features which have been specific to the Eastern European experience. Towards the end of the article, my frame of reference will be the themes 'utopianism' and 'Christian realism'. Suffice it to say at this point that by and large Eastern European theology of liberation is deeply suspicious of the former and as an antidote promotes the latter.

One could sum up the essence of the investigation in this (arguably self-contradictory) quotation from the Pope during the general audience on 21 February 1979 after his return from Mexico:

One must agree with the great contemporary theologian [Hans Urs von Balthasar] who justifiably demands a theology of liberation with a universal dimension. The particular circumstances may be different, but the reality of freedom itself is universal. The task of theology is to find the true meaning of freedom in the various, historically-based conditions that exist today. ${ }^{1}$

The question is: is there a single meaning of 'freedom', comprehensible to and applicable by Christians throughout the world, or will different circumstances in different parts of the world endow the word 'freedom' with different meanings?

\section{Elements in the 'Theology of Liberation' in Eastern Europe}

In Eastern Europe the churches have been not only physical havens for dissent but also islands where alternative values can flourish. Comments by a Catholic student on a protest hunger strike organised in 1977 in the church of St Martin, Warsaw, are 
characteristic. He points out that the church was chosen partly for reasons of safety the authorities wouldn't make arrests there - but partly also because the church is a place where truth and moral norms are upheld. 'Before the church lies the enormous task of reestablishing moral values in society, of fighting against demoralisation, cynicism, lack of belief in anything.'2

Specifically, three essential elements are generally perceived as essential in the operation of moral regeneration. These are: 'affirming freedom'; 'living in truth'; and 'overcoming fear'. These three are dynamically interrelated, as Fr Jerzy Popieluszko explains:

In order to remain spiritually free men, we must live in truth ... The source of our captivity lies in the fact that we allow lies to reign ... that we do not confront lies with the truth but keep silent or pretend that we believe in the lies. Thus we live in a state of hypocrisy. Courageous witnessing to the truth leads directly to freedom... The essential thing in the process of liberating man and the nation is to overcome fear. ... We can overcome fear only if we accept suffering in the name of a greater value. ${ }^{3}$

This is the essence of Christian 'liberation' in Eastern Europe. According to Fr Blachnicki, founder in the 1950 s of what became the 50,000 -strong 'Oasis' renewal movement in Poland,

Deeply rooted, if not always clearly formulated, in the consciousness of the striking and struggling masses is the intuitive conviction that a person is free when he witnesses to the truth which he knows and acknowledges. The Soviet system of enslavement, which is based above all on lies, awakens in them a deep yearning for liberation through the truth. ${ }^{4}$

The dynamic force which relates these three elements to one another is love. According to Aleksandr Ogorodnikov, writing in the mid-1970s, the spiritual world of young people in the USSR who have broken with Marxism and who are seeking a new faith is defined by two coordinates, love and freedom. ${ }^{5}$ From the mid-1970s until he was arrested and put into a labour camp Ogorodnikov ran the so-called 'Christian Seminar', which attracted participants young and old seeking a genuine faith. For its members, the Seminar was a realisation of the Christian concept of 'community' - 'a fraternal Christian community of love'. ${ }^{6}$ It is Christian love which creates the 'community' and binds it together; and an essential element in Christian love is freedom. The paradoxical combination of individual liberty and free unity constitutes the essence of the concept of sobornost', which is of such importance in Russian Orthodox theology; and the 'community' of the Seminar is seen by its members as an example of sobornost' at work. 'In this divided world we are trying to produce a community as the "unity of the spirit in the bond of peace"... It is not in isolated self-assertion, even if this involves creative activity, that we find the depths of our personality, but in fraternal love in the image of the Holy Trinity...' .

An important insight here is that it is love which is the inner creative dynamic of the Trinity. The small community bound together by love is the image of the Trinity. Stress on the concept of this kind of 'small community' as the essential kernel of renewal has been constantly recurring over the past 30 years among Christian groups throughout Eastern Europe.

From the late 1960s in Poland, 'Oasis' study groups met once a week for 'Gospelbased renewal of life'. 'From these tiny but dynamic groups the concept of the Living Church emerged - a church which expresses its vitality through communities of 
believers building their new lives together. ${ }^{9}$ The dissident Hungarian Catholic priest Fr György Bulányi, founder of the renewal movement 'A Bokor' ('The Bush'), wrote a work called Egyházrend (Church Order), completed in 1982. Discussing a desirable structure for the church of the future, he envisages the world's 700 million Roman Catholics belonging to 70 million basis communities, each led by a 'deacon'. The 'deacons' will belong as well to seven million second-level communities led by 'presbyters', who will in turn belong to 700,000 communities led by 'bishops', and so on up to level nine, at which point the members of the top community will take it in turns to be Pope. Bulányi envisages his basis communities as consisting of no more than a dozen members. The cement of the community is love; and to love, Bulányi argues, one must know the loved one intimately. ${ }^{9}$ More recently, at the Ampleforth Conference in the summer of 1990, the Polish Catholic writer and editor Stefan Wilkanowicz spoke as follows of his vision for the future of the church:

If the church is to be a family, this will come about in small communities where everybody knows everybody else. Fifty thousand people, or even ten thousand, cannot after all constitute a family. On this basis we can see that the structure of the church is tending to change. The parish has to be transformed into a community of communities. This can come about by the flexible application of pluralist principles, or by dividing the parish up into groups of a few hundred members or into basis communities... The experiences of different church basis communities are potentially of great importance here. On the vast territory of the USSR the Brazilian model of basis communities would be the most appropriate. In Poland, smaller communities are needed in order to do evangelistic work in the places where people live and work, to convey the Good News and to build a network of solidarity into everyday life. ${ }^{10}$

One more thing needs to be said about these communities. Their members will not be passive or given over to pietism, but active. What is more, their activity will be defined by 'love'; it will have nothing in common with the divisive class-based activism demanded of citizens of a Marxist-Leninist state. Action will be the consequence of shouldering one's personal responsibility for one's fellow-man rather than the consequence of identifying one's interests with an abstract 'proletariat'. The young Russian Orthodox activist Vladimir Poresh wrote in 1977 that

a man achieves freedom only by spiritual action, by acknowledging his sin and purifying his heart, and then too by performing irrevocable and hence responsible acts (burning bridges behind him). The outward action, the deed, done in complete responsibility, is the outward sign of deep spiritual change. We affirm social action as the path towards making spiritual life more profound. 11

Responding in 1978 in the samizdat journal Spektrum to the question, "how can we escape the constraints of a this-worldly existence?', the Czech Catholic theologian Fr Josef Zvěrina offers the same answer as Karl Marx once did: by acting. But our actions must be taken out of the context of a 'metaphsics of class hatred'; they must be based on love. 'I am challenged by my faith to perfect [the world]. In love, courage, justice and wisdom ... I strive to imitate its Creator. The created world is then a dynamic, open system.' ${ }^{12}$

The call to action is accompanied by an explicit rejection of pietism. Fr Blachnicki criticises that concept of faith whereby it 
is understood as an escape into the hereafter. The faithful withdraw 'into inwardness of spiritual bliss' and leave the things of this world to float. The inner personal relationship with Jesus, the Redeemer, is considered the essential element of Christianity, which fills one with joy so great that the problems of this world are forgotten ... This is a sentimental attitude to faith which alienates people from the realities of this world, which are dismissed as politics, or as the 'preoccupations of the children of this world'. 13

A declaration of March 1980 from a national congress of Oasis leaders rejected 'escapist tendencies' - the temptation to withdraw from everyday life into elitist communities which although they might offer comradeship based on the Gospel might keep their members from grappling with contemporary problems. ${ }^{14}$

\section{Similarities with Latin American 'Liberation Theology' - and Differences}

Having looked at some of the salient features of the 'theology of liberation' developed in Eastern Europe, we are now in a position to note some similarities with the 'liberation theology' of Christians in Latin America. There are four main areas of agreement: (a) stress on the small community as the seed for the growth of authentic Christian witness; (b) the fact that the life of the small community is seen as reflecting, and inspired by, the economy of the Trinity; (c) rejection of pietist quietism in the name of creative action in society; and (d) readiness to accept suffering and hardship for the sake of one's neighbour in the community - to become what liberation theologians call 'evangelically poor'.

An Eastern European Christian would recognise exactly what the Brazilian liberation theologians Leonardo and Clodovis Boff are describing when they write of

thousands of base communities, Bible-study circles, and centres of pastoral work among the people [which] have sprung up in virtually all parts of Latin America. In these communities Christians have been discovering communion as the structural and structuring theological value of the church ... the church should be the community of the faithful living in comradely relationships of sharing, love and service. ${ }^{15}$

He would also have no difficulty with the Boff brothers' argument that it is the mystery of the Trinity that

provides the prototype for what society should be according to the plan of the triune God: by affirming and respecting personal individuality, it should enable persons to live in such communion and collaboration with each other as to constitute a unified society of equals and fellow-citizens. ${ }^{16}$

He would also endorse their commendation of

those who place themselves and their strengths at the service of God and their sisters and brothers.... The evengelically poor are those who make themselves available to God in the realisation of God's project in the world... Sometimes love for the poor can become so intense that individuals give up their own station in life to share in the sufferings of the poor, even to the point of sharing their premature death. This is perfect liberation, for they have set themselves free from themselves. . . ${ }^{17}$ 
On the face of it, then, there are a number of similarities between the aspirations of those Christians in Latin America and those in Eastern Europe who are seeking 'liberation'. There are also, however, substantial differences. These differences have not been examined systematically. Why has there been so little dialogue between liberationists from these two parts of the world?

First of all, we should remember that systematic disinformation campaigns about the real status of religion in communist countries were waged by the secular authorities in those countries, often with the collusion of church leaders themselves. These campaigns were remarkably effective - a consequence in part of the inability or even unwillingness of well-meaning westerners to see through them. One aim of these campaigns was to minimise the suffering of religious believers in atheist states: the only ones who suffered, it was claimed, were fanatics and lawbreakers. In his book Christians and Marxists: the Mutual Challenge to Revolution, José Míguez Bonino briefly discusses what he calls the 'radical criticism' of Christianity by Marxism. This, he says,

should be received as an invitation for self-criticism, repentance and rebirth.

The 'persecution' of religion in communist countries poses a number of ... problems concerning the historical role of the Church, the nature of Constantinian Christianity, the class-captivity of some churches and many other questions which we cannot examine at this point. ${ }^{18}$

A student of Eastern European church affairs would be forgiven for thinking that this description betrays an inadequate understanding of the causes of the persecution of religion in Eastern Europe and the issues at stake in the struggle.

In these circumstances, it is hardly surprising that in a chapter of twelve pages dealing with 'Liberation Theology Worldwide' the Boff brothers are able to devote all of twelve lines to 'The Socialist Bloc'. 'There is little known', they write

about the state of theological thinking in this area, and still less about possible developments along the lines or influence of liberation theology. Just a few echoes come through, such as the Russian Orthodox Metropolitan Filaret's comment that the Roman document on liberation theology shows Rome to be afraid of it because it is afraid of socialism. ${ }^{19}$

Just who or what Metropolitan Filaret might be afraid of is not stated. He is in fact afraid of socialism too - the 'real existing socialism' of Brezhnev's Soviet Union.

This observation leads us on to identify a second a priori barrier to communication between 'liberationists' in Eastern Europe and Latin America. The former (like most other thinking citizens of their countries) had become completely cynical about concepts such as 'communism', 'Marxism', 'revolution': as far as they were concerned, these and many other terms were devoid of all meaningful content. They would therefore automatically be suspicious of any Christians attempting to use these words to say something significant about the role of Christians in contemporary society. In this context we should remember that while Latin American liberation theology dates its origin to the 1968 Latin American Bishops' Conference in Medellín, Colombia, it was the Warsaw Pact invasion of Czechoslovakia in that same year which finally put an end to Christian-Marxist dialogue in Eastern Europe. One was born just as the other died.

Bonino does indeed allude to the different status enjoyed by Marxism-Leninism in the two parts of the world and to the consequences of this difference as far as Christians are concerned: 
The European 'dialogue' frequently begins with the existence of two 'systems of truth', two self-contained and self-sufficient conceptual entities, almost two ideologies which confront each other. . . . In the Latin American situation, on the other hand, we are faced with men who are engaged in certain forms of action in relation to given conditions. These courses of action are, to be sure, related to theoretical views and horizons of meaning. But it is not as conceptual vision but as historical practice that they come into contact, opposition or co-operation.

But Bonino's conclusion is that 'we must not exaggerate this difference'. ${ }^{20}$ I would submit that, on the contrary, the difference is crucial. In Eastern Europe, the governing ideology was indeed a 'system of truth' which sought to exclude any other, and this fact had profound implications for the content of Christian liberation in that part of the world. Meanwhile, Christians in Latin America have been able to approach Marxism afresh. They have not been faced with an entrenched and fossilised system of 'fideist Marxism', to use Denys Turner's phrase. ${ }^{21}$ They have understood Marxism as a set of tools.

Placing themselves firmly on the side of the poor, liberation theologians ask Marx: 'What can you tell us about the situation of poverty and ways of overcoming it?' Here Marxists are submitted to the judgment of the poor and their cause, and not the other way around. Therefore, liberation theology uses Marxism as an instrument. It does not venerate it as it venerates the Gospel. ${ }^{22}$

To be at one and the same time a Christian and a Marxist in Eastern Europe had by 1968 become an impossibility. By contrast, as Bonino writes, 'To be a Christian and a Marxist is normal enough in, for example, South America where the culture is Catholic but the social situation is sufficiently bad to make revolution an obvious necessity. ... One is Christian and Marxist because that's how things are.'23

A sociologist analysing the phenomenon of the Solidarity movement in Poland in 1986 observed that "In the West "liberation movements" tend to be commonly associated with left-wing sympathies and the revolutionary ethos. Terms such as "progress" and "revolutionary change" have come to be identified with virtues like selflessness, responsibility and social conscience."24 Just the reverse was the case in Eastern Europe. Words such as 'revolution' and 'socialism' and even words such as 'politics' and 'peace' had become terminally compromised. As the same author notes, Solidarity members never spoke of themselves as belonging to a 'revolutionary' movement, preferring the phrase 'social movement'. ${ }^{25}$

A book by the Polish writer Adam Michnik was published in Paris in 1977 under the title Kościól, lewica, dialog (The Church and the Left - a Dialogue). Describing himself as a 'democratic socialist' Michnik invited the church in Poland to a dialogue for mutual benefit. The Polish Catholic theologian Fr Józef Tischner reviewed the book. He paid homage to Michnik's sincerity, but took issue with the 'democratic socialism' Michnik claimed he represented.

All this is very praiseworthy, but has it been thought through properly? In the first place, the concept of democracy involves the idea that power ultimately resides in the people, regardless of class differences, whereas the concept of socialism holds that the wielder of power is above all the 'nation's leading class' - the industrial proletariat. From the purely theoretical viewpoint, then, the concept of democratic socialism can be compared to a square circle. 
Tischner also took issue with Michnik's describing himself as belonging to the 'secular left'.

Does he realise how this sounds today to ordinary people ...? I cannot imagine that anybody standing as a candidate at some free election under the slogan 'secular left' would gain a parliamentary seat in this country after all that the nation has experienced. This does not mean that the nation are in favour of intolerance or discrimination. They have simply had enough. ${ }^{26}$

There are, then, some prima facie similarities between the 'liberation theology' of Latin America and 'theology of liberation' in Eastern Europe. We have also looked at some of the more obvious reasons why there has been lack of communication and comprehension between the two. But are there any differences of substance between them? I submit that there are, and that these are to be found in three main areas: in the answer to the question 'who are the poor?'; in the level of importance accorded to the renewal of the individual; and in the question of revolution versus gradualism in social change - utopianism versus realism.

\section{Who Are the Poor?}

Liberation theology in Latin America has taken an 'option for the poor'. So have liberationists in Eastern Europe.

In the 'Recommendations' of the Sixth National Congress of the Light-Life Movement in Poland in 1981 we find the following passage:

If, in the spirit of Christ's words, truth liberates man, then it follows that his enslavement depends on falsehood. Belief in the basic lie suggested to man by the tempter: 'You will become like gods', that is, a lie concerning metaphysical self-awareness, is the origin of man's state of serfdom and the ultimate source of all servility. ${ }^{27}$

The temptation 'You will become like gods' has seemed a particularly familiar one to Eastern European citizens. They have been able to see in their daily life the consequences of their rulers having succumbed, as they see it, to this temptation, with the consequent enslavement of the population. 'Let us simply say that the dictatorship of reason turned out to be the dictatorship of will, and the dictatorship of will, that of arbitrariness. The arbitrariness of one idea became a prison for all the rest. ${ }^{28}$ What is more, after 1968 the situation was perceived by many as not susceptible to alteration. What had previously manifested itself as a clear struggle between good and evil lapsed into stagnation of the kind associated with Brezhnev.

The Czech Catholic theologian Václav Benda wrote in 1979 that

Communism has ... been through two historical phases: in the '50s it resembled Lucifer, the most majestic of all God's angels, the spirit of deception, lies and eternal restlessness. This period was basically one of manichaean struggle between Good and Evil... . The communism of the last decade, however, has been more like Nietzsche's 'spirit of gravity' inert, grim and all-devouring. . . . The political Evil of today . . . is primarily an all-enveloping heaviness, which every citizen carries on his shoulders and within himself. . . .29

Interviewed in 1986, the Polish Catholic priest Fr Stanisław Malkowski noted that about 20 years previously - that is, in the late $1960 \mathrm{~s}$ - a rearrangement of the 
opposed forces in Polish society had made itself manifest: 'Twenty years ago the basic conflict, I think, was between dogmatism and liberalism - and dogmatism was represented by both communism and the church. But now the basic conflict is between nihilism and the values which are necessary for human life itself, such as love and solidarity. ${ }^{30}$

Clearly what we have to do with here is an existential crisis. Each individual is seen as facing a danger which is not only mortal but insidious. As the Russian Orthodox activist Vladimir Poresh put it in the summer of 1990 ,

we have been both witnesses and objects of an unprecedented degradation of humanity, unprecedented in its cruelty and profundity (cruel in the Stalinist era and profound in the post-Stalin period). This degradation was so profound that we hardly recognised it ourselves at the time and have not fully realised the extent of it even today. ... The liberation of man from the totalitarian state and its institutions, for the sake of man himself, is not just the main problem now facing our peoples, but the only one. ${ }^{31}$

Not just the main problem, but the only one. These are strong words. What price, then, the afflictions which are identified in Latin America as those from which people are to be liberated, and which are held to constitute poverty - lack of food, clothing, shelter, health care, education, work? It is certainly the case that abject physical poverty has not been a feature of the Eastern European scene. People have been deprived of luxuries, certainly, but they have generally not wanted for housing, basic foodstuffs and a secure job. And, indeed, observers from the West, and particularly from the Third World, have commented favourably on this aspect of communist society. They have seen it as confirmation of the positive contribution of communism to the overcoming of this kind of poverty. An official of the World Council of Churches, Ans J. van der Bent, reported on a WCC-sponsored consultation held in 1988 to bring together 'theological educators' from Eastern Europe and Latin America. One passage in his report is particularly interesting: 'Some representatives from Czechoslovakia and the German Democratic Republic insisted that new ways of perception have to be learned. ... The observation of Latin Americans that there are no poor or beggars in Prague and that the city is relatively clean was rather embarrassing to them.' ${ }^{32}$ In his survey van der Bent does not analyse or even speculate why this observation by the Latin American visitors should have been, of all things, embarrassing to the Eastern Europeans. Why this particular reaction? Because, I suggest, the Eastern Europeans knew it to be true that they were not poor in any straight forward sense - not 'socio-economically poor' as were their visitors - and yet they were poor, and knew themselves to be so, and were embarrassed that this irrelevant comparison should be obscuring a discussion of the distinctive type of poverty afflicting them. For Eastern Europeans, it was irrelevant that Marxism had done away with extreme poverty. In an important way, this fact made the threat from Marxism the more insidious. In the strange and paradoxical words of Fr Józef Tischner, 'On the one hand we were terrorised by the [Marxist] hope which promised the end of exploitation; as against this, we had a more general Christian hope, the essential element of which was human dignity.' ${ }^{33}$ Eastern Europeans were terrorised by the very thing which inspired their Latin American counterparts.

In broad terms, we can speak of a prerevolutionary liberation theology in Latin America and a postrevolutionary theology of liberation in Eastern Europe. In the words of Nicholas Lash, 


\begin{abstract}
Because every revolution that has occurred, or that can ever occur, within the historical process, represents the victory of particular interest, therefore there will always be those, after the revolution, whose needs and interests do not coincide with the group newly in power... . That same eschatological hope, that same trust in the transformative fidelity of a transcendent God, which led the Christian community to participate in the revolutionary process, now, on the same grounds, obliges it, or should oblige it, to "change sides'. The only 'permanent allies' of Christianity are, or should be, the weak and dispossessed: and their identity changes. ${ }^{34}$
\end{abstract}

Prerevolutionary poor as opposed to postrevolutionary poor, then; and we can be more precise about the latter and locate them and their distinctive characteristics in the Brezhnev years of stagnation. I noted earlier that the start of Latin American liberation theology coincided with the end of Christian-Marxist dialogue in Eastern Europe. It also coincided with the consolidation of the Brezhnev regime. The years of Stalinist terror had been a time of manichaean confrontation within society between good and evil. In the Brezhnev years, however, the battle line moved closer to home: the dividing line between good and evil, between integrity and compromise, was perceived as being located within every individual citizen. What is distinctive about Eastern European theology of liberation is its response precisely to this personal existential threat.

There is a radically different ordering of priorities, therefore. The Boff brothers speak of 'the need for a certain hierarchization of rights: first must come basic rights, the rights to life and the means of sustaining life (food, work, basic health care, housing, literacy); then come the other human rights: freedom of expression, of conscience, of movement, and of religion. ${ }^{35}$ From a report on meetings of Solidarity in Poland in 1980 , on the other hand, we learn that

It was generally held that 'truth' was the sole foundation on which a new and solid framework could be established. Indeed, the primary grievances levelled at the party-state related to evidence that the party had lied to and misled the population - that it had, in short, deliberately misrepresented objective truth. Considerably more emphasis was laid on the moral aspect of official falsification than on social injustice or the economic crisis. ${ }^{36}$

It is instructive to compare priorities for evangelisation. 'Part of integral evangelisation', say the Boff brothers, 'consists in fostering a sense of the inviolability of individual human beings and in guaranteeing their basic rights, particularly those in the social sphere. ${ }^{37}$ The way evangelisation was interpreted in Poland, says Fr Blachnicki, 'led. . . to its close identification with the concepts of truth and the cross and with the problem of overcoming fear'. ${ }^{38}$

In a section in their book entitled 'In the final analysis, who are the poor?', the Boff brothers write: 'This question is often posed by those who cannot really be counted among the poor.... They end up seeing themselves as one sort of poor - usually the "poor in spirit".' The Boff brothers then go on to speak of 'those who are actually poor (lacking the means to sustain life)'. These they describe as 'the socioeconomically poor': 'those who lack or are deprived of the necessary means of subsistence - food, clothing, shelter, basic health care, elementary education, and work'. ${ }^{39}$

We are now in a position to define three types of poor:

1 The evangelically poor: those who have chosen the road of self-denial and self- 
sacrifice on behalf of their brothers and sisters in the community. This choice is as we have seen a response to oppression common to both Latin America and Eastern Europe.

2 The socioeconomically poor: those whom the Boffs call 'actually poor'. These are predominantly the poor of Latin America.

3 The existentially poor: who would presumably be included among those whom liberation theologians dismiss as 'the poor in spirit', those who are compromised by having to 'live a lie'. These are predominantly the poor of Eastern Europe.

A writer on liberation theology in Latin America criticises those who try to interpret 'poor' as meaning 'poor in spirit', and comments disparagingly that in this context 'bondage' is usually interpreted as meaning 'inner slavery to sin'. ${ }^{40}$ Such 'slavery to sin' is, however, indeed what Christians in Eastern Europe are precisely afraid of. The great heresy of modern times, in the view of the Russian Orthodox philosopher Semen Frank, is the idea that 'human nature itself does not need improvement'. ${ }^{41}$ It is to Frank too that we owe an image, mentioned above, in his insight that 'the dividing line between the divine and the human, between the "church" and the "world", passes through the depth of every human heart'.42 This is an image which frequently recurs in the writings of Eastern European Christians, and what that line is said to divide is usually 'good' from 'evil'.

A point made forcibly by, among others, Václav Havel was that 'developed socialism' in Eastern Europe was - in its later stages at least - no longer a matter of the enforced imposition of unacceptable doctrines on a population which remains spiritually pure and uncompromised. The malaise goes deeper; it affects everyone, even the most humble, self-effacing and law-abiding. For Havel, there is

obviously in modern humanity a certain tendency towards the creation, or at least the toleration, of such a system. There is obviously something within human beings which ... paralyses every effort of their better self to revolt. Human beings are compelled to live within a lie, but they can be compelled to do so only because they are in fact capable of living in this way. . . ${ }^{43}$

And, as John Anderson puts it,

it is this complicity with the system that helps to keep it in place. Thus the greengrocer who places the slogan 'workers of the world unite!' amongst his onions and carrots may have no desire to preach. Yet his action is not without significance, for it shows that he accepts the rules of the game, thereby becoming a player in that game and thus enabling it to go on... Hence it is perhaps this mass acceptance of 'prescribed ritual', as much as any coercion, that keeps the system in place. ${ }^{44}$

\section{The Importance of Individual Renewal}

The citizens of both Latin America and Eastern Europe have been faced with unjust state structures in which violence has been institutionalised. The response of Latin American liberation theology has been to say that violence may be justified in order to overthrow these structures. By contrast, liberation movements in Eastern Europe have all espoused non-violence as an essential element in their programmes. Why?

As we have seen, the primary task for Christian liberationists in Eastern Europe is to undertake personal renewal. They hold that 'freedom' can be attained only if every individual overcomes fear and ceases living by lies. Latin American liberation 
theologians are apt to look askance at this programme of personal renewal, which for them smacks of pietism. Nevertheless, as we have seen, both Eastern Europeans and Latin Americans are committed to action: it is just that for the former, before meaningful and authentic actions can be performed, the personal integrity of the performer must first be confirmed. Westerners have tended to feel uncomfortable when faced with this ordering of priorities. They have felt not only that what these people are demanding is an optional extra, even a luxury, in a society where, after all, food, jobs and housing are guaranteed for all, but also that those who are making these demands are thereby singling themselves out as a dissenting elite and thus demonstrating that their aspirations are not shared by the 'ordinary' people on whose behalf they claim to speak.

Perhaps the most telling proof that these spokesmen were indeed articulating a concern felt instinctively as crucial to their survival by the 'ordinary' citizens of Eastern Europe, however, is the fact that the revolutions of 1989 were overwhelmingly peaceful. The insistence by 'ordinary' citizens that the communist regimes were to be overthrown peacefully reflected the fact that these same citizens had come to see the violence institutionalised in those systems not simply (or at all) as a threat to their physical wellbeing or existence but as a threat to their personal integrity. It would have been a defeat on these terms to have resorted to violence; and almost by definition a victory to use only the weapons of peace. An Oasis declaration of 1984 stated that an important principle in the struggle against institutionalised violence

is the renunciation of hatred, revenge, violence and all forms of terrorism. This principle cannot be based solely on practical grounds; it is not merely a way to avoid sacrifice and the shedding of blood. Rather, in this way a person maintains his dignity and becomes fully sovereign, achieving a spiritual victory over those who use unjust violence. The way of non-violence must become the Polish way to liberation because it is the way which always leads to victory, even when it demands sacrifice. It is the way of defeating evil with good, the way of saving human dignity, which is the ultimate goal of our struggle. $^{45}$

It is in insights such as these that we should seek the inner meaning of the "theology of suffering' so widespread in Eastern Europe, and so often misunderstood as a pathological thirst after martyrdom. It is very frequently not a retreat into dualism, quietism or pietism, but the reverse: the point is that a choice for suffering can be made, linked with the need for self-sacrificial action, and such a choice is an existential affirmation of the freedom and integrity of the individual. 'A genuine perception of life', says Vladimir Poresh, 'is a tragic perception. The tragic is the opposite of humdrum vulgarity, just as truth is the opposite of the lie. One must not run away from tragedy, but strive for it with all the strength of one's soul.,46

\section{Revolution versus Gradualism in Social Change}

In Latin America, church hierarchies have traditionally been in close alliance with the structures of oppression. The churches have provided theological justification for capitalist structures which in the name of individual freedom have denied that very freedom. In Eastern Europe, meanwhile, the officially recognised churches have found themselves in a different and rather paradoxical position. Those which have opted to cooperate with the regime, or which have been forced to do so, have had to give their assent to many policies which on the face of it are socially progressive: namely, to 
socialist policies. At the same time, the authorities have consistently pursued the aim of muting any distinctive church voice on current issues. Thus it is that opposition to government policies as voiced at various times by various Christian groups or churches in Eastern Europe has been couched in terms of a defence of traditional Christian values. Paradoxically, for instance, it was to the conservative Cardinal Mindszenty that the task of breaking the Catholic Church's traditional loyalty to the Hungarian state fell after the communists took over. ${ }^{47}$

The tendency towards doctrinal conservatism within the churches of Eastern Europe has been consolidated by the fact that these churches have tended to discourage theological speculation within their ranks: they have learned from experience that the secular authorities are only too ready to exploit differences of opinion and to favour one group over against another in the interests of the policy 'divide and rule'. In the late 1970 s a visitor wrote of the Catholic University of Lublin that it

still seems to suffer from lack of access to western theological scholarship. They get no encouragement from the Polish hierarchy, which regards what they call 'the latest western theological novelties' with suspicion, feeling it could be divisive and give the State just the opportunity it wants to drive a wedge into the Church's solid front. So there is little radical theology, and certainly no hint of 'liberation theology' of the kind being hammered out under totalitarian regimes of the Right. ${ }^{48}$

There are other, deeper reasons, however, why the churches in Eastern Europe, including those individuals and groups seeking 'liberation', have tended to retain a conservative theological outlook.

In 'developed socialism', 'truth' from the point of view of the authorities is what they choose at any time to say it is. The only defence against the arbitrariness of such a system is an assertion of unchanging principles anchored in 'divine law' which is at the same time 'natural law'. Now, an important phenomenon in recent Eastern European history is the fact that in many countries the broad secular opposition has found itself promoting values already being championed by the churches. These are the values which we have already identified as constituent elements in the Eastern European theology of liberation - the values of 'trust, openness, responsibility, solidarity, love' which Václav Havel, not himself a Christian, has described as the elements in the required 'existential revolution'. ${ }^{49}$ And it was the experience of 'developed socialism' which caused these values to become salient. In his book The Church and the Left - a Dialogue, referred to above, Adam Michnik writes that

The values of the Secular Left ... grew out of the Christian tradition ... For many years, however, the Secular Left and the Church had understood these values and their defence in very different ways. In the view of the Secular Left, these values had to be defended against the Church, since the ideals of the rights of man and the aspirations of the Church seemed to be in opposition... Only communist totalitarianism and the consciousness that common values were being threatened led to an eventual rapprochement. . . 50

During his visit to Poland in 1979, the Pope spoke out about the religious roots of social morality, and of the 'natural rights' of man as laws beyond the reach of human jurisdiction... The Catholic Church represented a defence of the rights and dignity of man; which express an objective moral order present in the world... Interestingly enough, the affirmation of Christian morality as a working basis for social relations was not necessarily determined 
by faith or religious affiliation. Non-believers gave equally strong support to the view that Christianity provided a foundation for a respect of human dignity and individual rights, and that the Catholic Church stood to defend these values. Throughout its existence, Solidarity maintained its position as a movement founded on the Christian tradition. ${ }^{51}$

A broad consensus, then, is found among Christians and non-believers about the values required to achieve the true 'liberation' of man. As far as the church in Eastern Europe was concerned, these were the values which it had traditionally championed: aspects of the eternal Truth of Christianity, as opposed to the contingent, man-made and cynically manipulated values proclaimed by those in power.

In order to contrast the Eastern European state of affairs with that in Latin America, let us look briefly at the history of Christian reformism in Latin America before Medellin. The first form of religiously inspired reformism in that part of the world was evolved in Chile from the early 1960s. The Catholic Church in Chile was distinguished amongst Latin American Catholic churches for its progressive stance on poverty and exploitation. Its programme was a Christian Democratic one. Both 'pluralist' and 'humanist', this programme was based on natural law, couched in neo-Thomist language and inspired by papal encyclicals such as Rerum novarum (1891). It welcomed support from all people of good will. 52 It was the failure of Christian Democracy in Chile to introduce effective social and political reform which led Christians in other parts of Latin America to develop a more 'scientific' (and more radical) approach. The new 'liberation theology' deliberately adopted the Marxist analysis of society. 'The crux of the matter', says Bonino,

is that Christian ethics has lacked - quite understandably until recent times and quite ideologically at present - an instrument for analysing the real dynamics of society and assessing the churches' active role in it. Therefore, the articulation of Christian love has been haphazard, arbitrary and sentimental and has easily fallen prey to the interests, 'very secular' as Marx said, of those in power. It is in this respect, I think, where Christian ethics can - and indeed I would say must - take Marxism seriously. It offers a scientific, verifiable and efficacious way to articulate love historically. ${ }^{53}$

We should note here the crucial fact that liberation theology claims to be adopting Marxism not as a creed, as a set of prescriptive maxims, but as a tool of analysis to enable its practitioners to discover precisely what is wrong with society and why. 'As a perspective the new Catholicism has no program,' says Thomas Sanders, 'except a concern for liberation. . . By deprogramming its thought it succeeded in freeing itself from the guideline thinking of the Chilean model ... ${ }^{54}$ Denys Turner, who resolutely distinguishes 'fideist' Marxism of the Eastern European kind from Marxism as praxis, writes of what he sees as the pure Marxist understanding of 'revolution':

Any revolution is the struggle with oppression in the name of a liberty which the revolutionaries know that they will be unable to describe until the oppression has been overthrown... Marxism cannot know the morality which it is the struggle to articulate. Morality, in so far as we can know it, is the struggle that there should be morality.... Marxism is morality, not as being but a rival set of answers to bourgeois moral questions, but as the condition of the possibility of morality. ${ }^{55}$

The Marxist philosopher Ernst Bloch, frequently quoted by Latin American liberation 
theologians, calls what he propounds a 'philosophy of hope', described by one commentator as a

philosophy of the 'not-yet'. Reality is seen as a sea of possibilities; it is open to the advent of the new. ... A philosophy of hope, a philosophy of the notyet future, understands reality from a perspective which expects the radically new and unpredictable to break in from the future of possibility. ${ }^{56}$

As far as values are concerned, then, Latin American liberation theology adopts a contextualising approach.

Traditional Catholic social thought tried to define how the Christian individual and the church might bring given processes into correlation with predetermined norms... [The new radicals, however, say] that the options and even thinking of the Catholic actor and the church will be defined by the context. The Catholic is oriented by certain values, but their expression is conditioned by the problems and possibilities at hand. One does not shape the context by a preconditioned concept of justice, but the nature of justice is defined by the historical process. ${ }^{57}$

What we need to note here is that this approach is the approach appropriate to pure Marxism, Marxism as praxis. Even though the Marxism adopted by Latin American liberation theologians is far removed from Stalinist or even Brezhnevite 'fideist' Marxism, then, the outcome will still be viewed with grave scepticism by Christian liberationists in Eastern Europe. For it is precisely Marxist teaching about the contingent, contextual nature of morality that they reject. The Marxist systems of Eastern Europe, proclaiming the future utopia, have produced nothing but the most chronic moral relativism. It is therefore unsurprising (but one more piece of evidence for western critics so inclined to interpret as simple reactionary obscurantism) that Fr Jerzy Popieluszko claimed simply that 'the Truth is unchangeable'. ${ }^{58}$

In general throughout Eastern Europe, then, the tendency is to assert that fundamental human values, values common to all humanity, have an unassailable base in traditional Christian teaching, and that they are aspects of an unchanging truth. These are values, moreover, which find their articulation in the moral activity of free individuals. The Eastern European prescription for social change is therefore minimalist rather than maximalist, gradualist rather than revolutionary. Change proceeds from the individual to society. In Fr Popieluszko's analysis, 'external freedom or political freedom' are the consequence of 'freedom of spirit and faithfulness to the truth'. 59 'Love your neighbour' means precisely that. The Russian Orthodox lay activist Tat'yana Goricheva has interesting things to say about the interpretation placed on this commandment by young Christian neophytes in Russia in the 1970s. By 'neighbour', she writes, they understand 'the nearest one in space. .. In the contemporary world, love of what is far off is usually a lack of honesty. ${ }^{60}$ In testimonies from Christian activists from all over Eastern Europe, time and again we see the same movement commended: from the individual into society. The section 'Christian politics' from the 1990 Declaration of Principles of the Russian Christian Democratic Movement reads as follows:

The basic task of Christian life is to achieve perfection, for it is written: 'Be ye perfect, as your Father in Heaven is perfect'. This commandment is taken as meaning in the first place self-perfection, since it is prescribing to us a particular inner spiritual structure. The process of perfection consists in developing within ourselves the power of the grace of love. This becomes a 
kind of emanation outwards and of necessity expresses itself as moral activeness, as loving activity for the good of our neighbour, as an outpouring of good into the world. In this way the moral activity of a Christian coincides with the task of perfecting the world. ${ }^{61}$

Ten years earlier, young Slovak Catholics had written as follows to their fellowCatholics abroad:

Our future lies in young Christian families which share their spiritual life. . . .

Our future lies in small communities of believers - a few people of the same age and with the same interests who try to live their faith fully and so are an example and a help to those around them... Our future is also in our Christian movements. ... Our hope lies also in solidarity and friendship with believers in other countries. ...62

One of the leaders of the Russian Christian Democratic Movement, Viktor Aksyuchits, spoke to the Congress of People's Deputies in 1990 on the subject of liberation from communist ideology. "We see that in all the countries which have experienced communist ideology, a return to traditional values is taking place... Traditional values are above all a rejection of revolutionary ideology, of revolution that is, of extremism.' ${ }^{63}$ The practical programmes adopted in Eastern Europe by movements influenced by a theology of liberation have been consciously gradualist. Solidarity, for example, operated throughout its existence on the principle of gradualist reform. 'The majority of its members genuinely believed that a single political act would achieve nothing, and that success could come only as a result of laborious endeavours to reweave the very fibres of Polish society.64 In an article written in 1980, the Czech Catholic philosopher Václav Benda placed hopes for a political solution to his country's problems on Catholic activists, whom he saw as possessed of an essential 'realism' and as harbouring no illusions about the possibility of a future socialist utopia on earth. He proposed a new 'radically conservative' approach to politics, an approach which would involve no allegiance to ideology but which would be marked by a down-to-earth pragmatism which would promote human rights, democracy and social justice. ${ }^{65}$ One of the first books to be republished by the new 'Open Christianity' society founded in St Petersburg by Vladimir Poresh in 1988 was Yeres' utopizma (The Heresy of Utopianism) by Semen Frank. In his writings Frank distinguishes two tasks. The task of the individual is self-perfection: the overcoming of evil by good. The task of men in society is to set up a system which will facilitate this achievement of individual selfperfection. Society as such, however, is not perfectible. 'Genuine Christian wisdom necessarily includes the consciousness of the inevitability in the world of a certain minimum of imperfection and evil.' 66

The practical programmes of Eastern European liberation movements are often disconcertingly heterogeneous lists of very specific and limited tasks, the achievement of which will, however, be imbued with immense significance on the moral level. The Sixth Congress of the Oasis movement described 'the diaconate of liberation' as comprising three tasks: 'liberation by testifying to the truth'; 'liberation from alcoholism'; and 'liberation from the most developed form of egoism, dependence on abortion'. ${ }^{67}$ The culmination of the Pope's second visit to Poland in 1983 was a sermon he delivered in Kraków on 22 June. He drew his listeners' attention to what he described as the 'plain' and 'ordinary' character of their activities.

Their 'sanctity', the Pope said, reflected not so much the heroism of acts as the 'heroism of their entire lives'. This 'heroism', the Pope went on, centred on 
their 'perseverance' in efforts to apply Christian values and principles to all aspects of their work. This is why, the Pope reminded his audience, they could be regarded as 'symbols of moral victory'. ${ }^{68}$

Christians concerned with 'liberation' in Eastern Europe have developed, then, a distinctive form of Christian realism which combines a programme of self-renewal and self-liberation by the individual with a programme of gradual and peaceful reform in society. The two programmes are intimately linked. And it is the job of the church, in the view of Fr Malkowski, 'to say that there is a strong connection between inner freedom and external freedom, between the inner evolution of hearts and spirits, and external evolution'. ${ }^{69}$

\section{Notes and References}

1 Quoted in Fr Franciszek Blachnicki, 'A theology of liberation - in the Spirit', Religion in Communist Lands (RCL), vol. 12, no. 2, 1984, pp. 157-67, here p. 157.

2 'Reflections from the church of St Martin', Spotkania, no. 1 (London edition), 1978, pp. 53-62, here p. 59, quoted in Piotr Jeglinski and Alexander Tomsky, 'Spotkania journal of the Catholic opposition in Poland', $R C L$, vol. 7, no. 1, 1979, pp. 23-8, here pp. 26-7.

${ }^{3}$ Fr Jerzy Popieluszko, sermon, October 1982, quoted in Grazyna Sikorska, “ "To kneel only before God": Fr Jerzy Popiełuszko', $R C L$, vol. 12, no. 2, 1984, pp. 149-56, here p. 154.

4 Fr Blachnicki, op. cit., p. 164.

5 Aleksandr Ogorodnikov, 'Kul'tura katakomb, k opytu istorii pokoleniya', Obshchina, no. 2, 1978, quoted in Philip Walters, 'The ideas of the Christian Seminar', $R C L$, vol. 9, nos 3-4, 1981, pp. 111-19, here p. 111.

6 Obschchina, no. 2 (incomplete text), Arkhiv samizdata, no. 3452, p. 16.

7 V. Burtsev et al., 'Molodaya Rossiya - k molodoi Amerike' (samizdat), 1979, pp. 2-3, quoted in Philip Walters, op. cit., p. 112.

${ }^{8}$ Grazyna Sikorska, 'The Light-Life movement in Poland', $R C L$, vol. 11, no. 1, 1983, pp. 49-55, here p. 51.

9 Michael Walsh, 'Father Bulányi's church order', $R C L$, vol. 15, no. 1, 1987, pp. 79-82.

10 Stefan Wilkanowicz, 'The problems and tasks confronting the church in Central and Eastern Europe today', $R C L$, vol. 19, nos. 1-2, 1991, pp. 30-6, here pp. 35-6.

11 Vladimir Poresh, 'Dai krovi - priimi dukh', Obshchina, no. 2, pp. 21-3, trans. in $R C L$, vol. 9, nos. 3-4, 1981, pp. 122-4.

12 Fr Josef Zvěřina, 'Svět je mnohorozměrný', Spektrum, no. 1 (Index on Censorship), 1978, p. 39; quoted in Alexander Tomsky, 'Spektrum: a journal from the Czech cultural hinterland', $R C L$, vol. 8, no. 3, 1980, pp. 180-7, here p. 186.

13 Fr Blachnicki, op. cit., p. 158.

14 'Declaration of the Fifth National Congress of the Light-Life Movement', $R C L$, vol. 11, no. 1,1983 , pp. 60-3.

15 Leonardo and Clodovis Boff, Introducing Liberation Theology (Burns and Oates, Tunbridge Wells, 1987), p. 59.

16 ibid., pp. 51-2.

17 ibid., pp. 48-9.

18 José Míguez Bonino, Christians and Marxists: the Mutual Challenge to Revolution (Hodder and Stoughton, London, 1976), p. 123.

19 Leonardo and Clodovis Boff, op. cit., p. 82.

20 Bonino, op. cit., p. 29.

21 Denys Turner, Marxism and Christianity (Blackwell, Oxford, 1983), passim.

22 Leonardo and Clodovis Boff, op. cit., p. 28.

23 Bonino, op. cit., p. 121. 
${ }^{24}$ Ireneusz Krzeminski, 'Solidarity - the meaning of the experience. A sociological survey', $R C L$, vol. 14, no. 1, 1986, pp. 4-16, here p. 6.

25 ibid., p. 5.

26 Fr Józef Tischner, Polski kstalt dialogu (Spotkania, Paris, 1981), a critique of the book by Adam Michnik, Kościól, lewica, dialog (Paris, 1977). A translation of parts of the last chapter of Fr Tischner's book appears in $R C L$, vol. 9, nos 3-4, 1981, pp. 139-46.

27 'Recommendations of the Sixth National Congress of the Light-Life Movement', $R C L$, vol. 11 , no. 1,1983 , pp. $63-6$, here p. 64 .

28 Tat'yana Goricheva, 'The existential and religious significance of unofficial Soviet culture', 1979, translated in $R C L$, vol. 8, no. 3, 1980, pp. 230-2, here p. 232.

29 Václav Benda, 'Catholicism and politics: the origins of the present situation and how it may develop', 1979, translated in $R C L$, vol. 9, nos 1-2, 1981, pp. 60-5, here p. 64.

30 'The church in Polish society' (interview with Fr Malkowski), $R C L$, vol. 14, no. 3, 1986, pp. 283-9, here p. 289.

31 Vladimir Poresh, 'Faith and lack of faith in Russia', $R C L$, vol. 19, nos 1-2, 1991, pp. $75-81$, here p. 78 .

32 Ans J. van der Bent, 'Doing theology in an East European and Latin American context', Occasional Papers on Religion in Eastern Europe (OPREE), vol. 8, no. 6, 1988, pp. 36-40, here p. 38.

33 'Poland: the meaning of "dialogue" between the church and the "left", $R C L$, vol. 9, nos 3-4, 1981, pp. 139-46, here p. 143.

${ }^{34}$ Nicholas Lash, $A$ Matter of Hope: a Theologian's Reflections on the Thought of Karl Marx (Darton, Longman and Todd, London, 1981), p. 289.

35 Leonardo and Clodovis Boff, op. cit., p. 61.

36 Krzeminski, op. cit., p. 9.

37 Leonardo and Clodovis Boff, op. cit., p. 61.

38 Fr Blachnicki, op. cit., p. 166.

39 Leonardo and Clodovis Boff, op. cit., pp. 46-7.

40 Marc Kolden, 'Marxism and Latin American liberation theology', in Wayne Stumm (ed.), Christians and the Many Faces of Marxism (Augsburg Publishing House, Minneapolis, 1984), pp. 123-31, here p. 127.

4 Semen Frank, Svet vo t'me (YMCA, Paris, 1949), p. 373; translation by Boris Jakim, The Light Shineth in Darkness (Ohio University Press, Athens, 1989), p. 218.

42 Semen Frank, Dukhovnyye osnovy zhizni (YMCA, Paris, 1930), p. 202; translation by Boris Jakim, The Spiritual Foundation of Society (Ohio University Press, Athens, 1987), p. 114.

43 Václav Havel, 'The power of the powerless', in John Keane (ed.), The Power of the Powerless (London, 1985), p. 38.

44 John Anderson, 'Courtesy towards God: religion and change in Eastern Europe', $R C L$, vol. 18 , no. 2,1990 , pp. 100-25, here p. 111.

45 'Suwerenność wewnętrzna', Deklaracja Carlsberska, 29 August 1982, p. 4, quoted in Paul Keim, 'A Polish strategy for non-violent change', $R C L$, vol. 11 , no. 2, 1983, pp. 161-9, here p. 164.

46 Poresh, 'Dai krovi - priimi dukh', p. 123.

47 See Janos Wildmann, 'Hungary: from the ruling church to the "church of the people" ', $R C L$, vol. 14, no. 2,1986 , pp. $160-71$.

48 Roger Symon, 'Poland: the Catholic University of Lublin 1918-1978', RCL, vol. 6, no. 4, 1978, pp. 222-6, here p. 224.

49 Havel, op. cit., pp. 92-3.

so Adam Michnik, 'The church and the left - a dialogue', in F. Slinitsky et. al., Communism and Eastern Europe (New York, 1979), p. 90.

st Krzeminski, op. cit., p. 9.

52 See Thomas G. Sanders, 'The new Latin American Catholicism', in D. Smith (ed.), Religion and Political Modernization (Yale University Press, New Haven and London, 
1974), pp. 282-302. For the history of Christian Democracy in Chile, see also Bonino, op. cit., pp. 21-3. For the development of papal teachings on social issues and comment on the major twentieth-century encyclicals, see Arthur F. McGovern SJ, "Catholic social teachings: a brief history', in Pedro Ramet (ed.), Catholicism and Politics in Communist Societies (Duke University Press, Durham and London, 1990), pp. 28-45.

53 Bonino, op. cit., pp. 114-15.

${ }^{54}$ Sanders, op. cit., p. 299.

$\$ 5$ Turner, op. cit., pp. 123-4.

56 James M. Childs Jr, 'Marxist humanism and the hope of the Gospel', in Stumm, op. cit., pp. 110-22, here p. 113. Bloch understands the coming Kingdom in humanist terms, as involving the establishment of a utopia of human fulfilment. In The Principle of Hope he writes that 'God appears ... as the hypostasized ideal of the as yet truly undeveloped essence of man: he appears as Utopian entelechy (actuality).' The apparent similarities with 'God-Building' ('bogostroitel'stvo') as developed by the Marxists Gor'ky, Lunacharsky and Bogdanov in early twentieth-century Russia would repay further investigation.

57 Sanders, op. cit., pp. 290-1.

58 Fr Jerzy Popieluszko, sermon, October 1982, quoted in Sikorska, op. cit., p. 154.

59 loc. cit.

60) Tat'yana Goricheva, 'Khristianstvo, kul'tura, politika', Vol'noye slovo, no. 39, p. 15. Here, as so often, a theme of the 1970 s and 1980 s echoes a theme of the immediately prerevolutionary period in Russia. While the revolutionaries of the early twentieth century were advocating the sacrifice of the welfare of the contemporary individual in the name of a promised future utopia for mankind, religious thinkers were responding with a stress on the prime duty as they saw it of responsibility to one's nearest neighbour: 'love for what is near ('lyubov' $k$ blizhnemu') rather than 'love of the distant' ('lvubov'kdal 'nemu'). See S. L. Frank, 'Fr. Nitsshe i etika "lyubvi k dal'nemu'”, Problemy idealizma (Moscow, 1903), pp. 137-95; G. L. Kline, Religious and Anti-religious Thought in Russia (Chicago, 1968), pp. 48-9; Philip Walters, 'The ideas of the Christian Seminar', $R C L$, vol. 9, nos 3-4, 1981, pp. 111-26.

61 'Deklaratsiya RKhD Dvizheniya', RKhDD: sbornik materialov (Moscow, 1991), pp. 21-35, here p. 29.

62 From a samizdat letter to young fellow-Catholics, Spring 1980, partly translated in $R C L$, vol. 10, no. 1, 1982, pp. 50-3.

63 'V. Aksyuchits. Vystupleniye na l s'yezde narodnykh deputatov RSFSR', RKhDD: sbornik materialov, pp. 58-66, here p. 62.

64 Krzeminski, op. cit., p. 6.

65 'Catholicism and politics in Czechoslovakia', $R C L$, vol. 9, nos 1-2, 1981, pp. 60-5.

66 Frank, Svet vo t'me, p. 312; Frank, The Light Shineth in Darkness, p. 179.

67 'Recommendations of the Sixth National Congress of the Light-Life Movement', p. 66.

68 J. B. de Weydenthal, 'The Pope's pilgrimage to Poland', $R C L$, vol. 12, no. 1, 1984, pp. 69-76, here p. 75 .

69 'The church in Polish society', p. 288. 